Abstracta Iranica Abstracta Iranica

Revue bibliographique pour le domaine irano-aryen

Volume 22 | 2001

Comptes rendus des publications de 1999

Madāres-e jadīd dar dowre-ye Qājāriyye : bāniyān va pišrovān. Tehrān, Markaz-e Našr - Našr-e Dānešgāhī, 1999/1378, 660 p.

Florence Hellot

\title{
OpenEdition
}

1 Journals

\section{Édition électronique}

URL : http://journals.openedition.org/abstractairanica/36585

DOI : 10.4000/abstractairanica.36585

ISSN : 1961-960X

Éditeur :

CNRS (UMR 7528 Mondes iraniens et indiens), Éditions de l'IFRI

\section{Édition imprimée}

Date de publication : 15 mai 2001

ISSN : 0240-8910

Référence électronique

Florence Hellot, « Madāres-e jadīd dar dowre-ye Qājāriyye : bāniyān va pīšrovān. Tehrān, Markaz-e Našr Našr-e Dānešgāhī, 1999/1378, 660 p. », Abstracta Iranica [En ligne], Volume 22 | 2001, document 246, mis en ligne le 15 février 2010, consulté le 10 octobre 2020. URL : http://journals.openedition.org/ abstractairanica/36585; DOI : https://doi.org/10.4000/abstractairanica.36585

Ce document a été généré automatiquement le 10 octobre 2020.

Tous droits réservés 
Madāres-e jadīd dar dowre-ye Qājāriyye : bāniyān va pīšrovān. Tehrān, Markaz-e Našr - Našr-e Dānešgāhī, 1999/1378, 660 p.

Florence Hellot

1 Il s'agit d'un ouvrage très structuré qui aborde d'abord les changements sociaux et culturels de l'Iran à l'époque des Qâjârs. Il décrit ensuite les formes d'enseignement public, les écoles traditionnelles et les écoles nouvelles, ainsi que la manière dont évoluent les méthodes d'enseignement. Les écoles étrangères sont signalées. Le lecteur apprécie les longs passages sur les initiatives individuelles et, surtout, sur les premiers journaux. La partie qui se rapporte à l'action conjuguée des écoles et de la révolution constitutionnelle est particulièrement intéressante : elle s'attarde longuement sur les écoles des villes d'Azerbaiijân, sur la récupération ou la critique qui en est faite par les " anjoman » et les différents partis en présence à Tabriz. Le bilan qui en est donné est intéressant; les photos reproduites en font un ouvrage incontournable que l'on souhaiterait enrichir encore des remarques des envoyés étrangers en Perse à la même époque et du travail réalisé par Homā Nāṭeq sur les écoles françaises en Perse.

\section{INDEX}

Thèmes : 4.2.1. Safavides et Qâjârs 
AUTEURS

FLORENCE HELLOT

Paris 